\title{
NOTE ON ABBREVIATIONS
}

ALL ABBREVIATIONS OF MODERN JOURNALS AND books and ancient sources conform to the guidelines outlined in the American Journal of Archaeology 104 (2000), 10-24. 
THIS PAGE INTENTIONALLY LEFT BLANK 
MONUMENTALITY IN ETRUSCAN AND EARLY ROMAN ARCHITECTURE 
THIS PAGE INTENTIONALLY LEFT BLANK 